\title{
Differences in Insulin Action as a Function of Original Anatomical Site of Newly Differentiated Adipocytes Obtained in Primary Culture
}

\author{
Carole Sztalryd, Salman Azhar, and Gerald M. Reaven \\ Department of Medicine, Stanford University School of Medicine; and Geriatric Research, Education, and Clinical Center, \\ Department of Veterans Affairs Medical Center, Palo Alto, California 94304
}

\begin{abstract}
Stromal vascular cells were isolated from adipose tissue obtained from three different anatomical locations: epididymal (EPI), retroperitoneal (RP), and dorsal subcutaneous (SC), and allowed to differentiate in primary tissue culture. Cell number, protein concentration, glycerophosphate dehydrogenase, and lipoprotein lipase activity were similar in cells obtained from the EPI, RP, and SC regions, as were total insulin binding and the affinity of insulin for its receptor. However, both maximal insulin receptor tyrosine kinase activity and insulin-stimulated phosphorylation of the insulin receptor were significantly lower $(P<0.05)$ in cells cultured from the SC region. In addition, newly differentiated adipocytes from the $S C$ region were less sensitive to the ability of insulin to stimulate glucose uptake, and maximal insulin-stimulated glucose uptake by these cells was also significantly lower $(P<0.05)$ when compared to cells obtained from the two other regions. Since these studies were performed on adipocyte precursor cells, allowed to differentiate to a similar degree in primary culture, the observed differences in insulin receptor phosphorylating activity, as well as the ability of insulin to stimulate glucose uptake appear to be intrinsic to adipose tissue from the three sites. (J. Clin. Invest. 1991. 88:1629-1635.) Key words: tyrosine kinase activity • differentiation • insulin binding • adipocyte precursor • glucose uptake
\end{abstract}

\section{Introduction}

It has been apparent for some time that the ability of insulin to stimulate glucose uptake tends to be decreased in obese individuals $(1,2)$. More recently, it has been suggested that accumulation of adipose tissue in the abdominal region, as evidenced by an increase in waist to hip girth, has uniquely deleterious effects on insulin action $(3,4)$. The interpretation of these latter results has been that the metabolic behavior of fat tissue varies as a function of its anatomical location. Experimental support for this general hypothesis has come from experiments demonstrating that adipocytes isolated from different anatomical regions can vary significantly in terms of cell number, responsiveness to glucocorticoids and sex hormones, and rate of catecholamine-induced lipolysis (5-8). However, there is relatively little evidence showing that insulin regulation of adipocyte metab-

Address correspondence to G. M. Reaven, M. D., Geriatric Research, Education, and Clinical Center (182-B), Veterans Affairs Medical Center, 3801 Miranda Avenue, Palo Alto, CA 94304.

Received for publication 31 October 1990 and in revised form 11 June 1991.

The Journal of Clinical Investigation, Inc.

Volume 88, November 1991, 1629-1635 olism changes with source of fat tissue, and what data are available deal primarily with the ability of insulin to inhibit catecholamine-induced lipolysis $(9,10)$. Indeed, we are only aware of one study which has addressed the question of the effect of regional fat distribution on insulin-stimulated glucose uptake (11), showing that this effect of insulin was increased in adipocytes obtained from epididymal as compared to dorsalsubcutaneous tissue. Although these data support the view that the ability of insulin to stimulate glucose uptake by adipose tissue changes with the anatomical source of the fat cells, its significance is confounded by the fact that freshly isolated adipocytes obtained from different regions also vary in mean cell size and cell number, as well as in terms of their microenvironment. Thus, results of such studies do not provide unequivocal answers as to whether or not intrinsic differences in fat cell response to insulin exist. One obvious way to address this question is to isolate adipocyte precursors from different anatomical sites, allow them to differentiate into mature fat cells in culture under uniform conditions, and then study the ability of insulin to modulate insulin action in a situation in which differences in fat cell size and number and microenvironment no longer exist. If this can be accomplished it becomes possible to see if there are intrinsic differences in insulin action on adipocyte glucose metabolism as a function of anatomical site. The study to be presented was initiated to accomplish this task.

\section{Methods}

\section{Animals}

Male, weanling, Sprague-Dawley rats were used for individual experiments. They were decapitated, and adipose tissue immediately removed from three regions: epididymal (EPI), ${ }^{1}$ retroperitoneal (RP), and dorsal subcutaneous (SC). Adipose tissue from 25-30 rats was used for each culture.

\section{Chemicals}

Reagents were obtained from the following sources: collagenase (Worthington Biochemical Corp., Freehold, NJ); Triton X-100, $N$-acetyl-D-glucosamine, polyethylene glycol, aprotinin, BSA (fraction V), polyamino acid polymer $\mathrm{Glu}^{80} \mathrm{NaTyr}^{20}$ [poly $\left(\mathrm{GLU}^{80}: \mathrm{Tyr}^{20}\right.$ )], Na benzoyl-L-arginine ethyl ester (BAEE), disuccinimidyl suberate, and paramethylsulfonylfluoride (PMSF) (Pierce Chemical Co., Rockford, IL); wheat germ agglutinin (Vector Laboratories, Inc., Norwalk, CT) A14${ }^{125}$ I monoiodoinsulin and I.N. Crystalline porcine insulin (gift of Dr. B. H. Frank, Eli Lilly); B26- ${ }^{125}$ I human monoiodoinsulin (Amersham Corp., Arlington Heights, IL); $\left(\gamma-{ }^{32} \mathrm{P}\right)$ adenosine-5'-triphosphate (10$40 \mathrm{Ci} / \mathrm{mmol}$ ) (E. I. du Pont de Nemours, Boston, MA); 2-desoxyglucose ${ }^{14} \mathrm{C}$ (New England Nuclear, Boston, MA). All other chemicals were prepared from standard commercial sources.

1. Abbreviations used in this paper: EPI, epididymal; GPDH, glycerophosphate dehydrogenase; LPL, lipoprotein lipase; RP, retroperitoneal; SC, dorsal subcutaneous; SV, stromal vascular. 


\section{Cell harvesting techniques and culture conditions}

Stromal vascular (SV) cells were obtained and pooled separately from EPI, RP, and SC by means of collagenase digestion as described previously (12), and cultures seeded at a density of $2.510^{5}$ cells in $35-\mathrm{mm}$ (diameter) plastic culture wells (6-well multiwell plates). Cells were first grown in DMEM containing $4.5 \mathrm{~g} /$ liter glucose and $25 \mathrm{mM}$ Hepes, supplemented with $10 \%$ defined FCS, penicillin $(10,000 \mathrm{U} / \mathrm{ml})$, streptomycin $(10,000 \mu \mathrm{g} / \mathrm{ml})$, and insulin $(0.01 \mathrm{nmol} /$ liter $) .12 \mathrm{~h}$ after plating, cultures were washed with serum-free medium and replenished with fresh culture medium as defined above. The same medium was replenished at 2-d intervals until the cells were about to reach confluence (4-5 d postplating), at which point cultures were replenished with DMEM supplemented with $1 \% \mathrm{FCS}$, insulin (1 nmol/liter), and Intralipid ( $1 \mu \mathrm{l} / \mathrm{ml}$; KB Kabivitrum, Clayton, NC). This latter medium was also renewed at 2-d intervals. Cultures were terminated 8-10 d later, and assayed for cellular growth, degree of differentiation, estimates of insulin action, and study of insulin receptors.

For each culture and each tissue, 14 plates containing 6 wells were seeded. The following culture assays were performed.

\section{Culture assays}

Total cell number. Cells were removed from one culture well by means of trypsinization $\left(5 \mathrm{~min}\right.$ at $37^{\circ} \mathrm{C}$ ) with trypsin-EDTA (Gibco Laboratories, Grand Island, NY) and quickly sampled for counting in a hemocytometer.

Cellular protein content. Protein content was determined in one culture well by assay (Bio-Rad Laboratories, Richmond, CA) (13).

Degree of cell differentiation. Heparin-releasable lipoprotein lipase (LPL) activity was assayed in two wells according to the method of Nilsson-Ehle et al. as modified by Glick and Rothblat $(14,15)$, and expressed as $\mu \mathrm{U}$ of free fatty acid released per hour per milligram protein. To assay for glycerophosphate dehydrogenase (GPDH), cells from two wells in each plate were just scraped free with a rubber policeman and homogenized with a sonifier (Branson Sonic Power Co., Danbury, CT) $(10 \mathrm{~s}$ at $30 \mathrm{~W})$ in $25 \mathrm{mM}$ Tris buffer and $1 \mathrm{mM}$ EDTA. Aliquots of the supernatant were then tested for rate of oxidation of NADH at 340 $\mathrm{nm}$. One unit of GPDH activity is defined as the oxidation of $1 \mathrm{nM}$ of $\mathrm{NADH} / \mathrm{mm}$ (16).

Insulin binding. Binding experiments were performed directly in culture dishes as previously described (17). Briefly, cells are preincubated for $2 \mathrm{~h}$ at $37^{\circ} \mathrm{C}$ with serum free DMEM without added insulin, washed with phosphate buffer, and incubated for $30 \mathrm{~min}$ at $37^{\circ} \mathrm{C}$ with $0.5 \mathrm{ml}$ of DMEM containing $3 \% \mathrm{BSA}, \mathrm{A} 14^{-125} \mathrm{I}$ insulin $(25,000 \mathrm{cpm})$, various concentrations of unlabeled insulin $(0.05 \mathrm{nmol} / \mathrm{liter}-15 \mathrm{nmol} /$ liter), and bacitricin ( $1 \mathrm{mmol} / \mathrm{liter})$. At the end of the incubation period, cells were washed thoroughly, solubilized with $2 \mathrm{ml}$ of $0.1 \mathrm{~mol} /$ liter $\mathrm{NaOH}$, and ${ }^{125} \mathrm{I}$ radioactivity determined in a gamma counter.

Solubilization and partial purification of insulin receptors. Solubilization and partial purification of solubilized insulin receptors was carried out as described by Hedo et al. (18). Cells from five 6-multiwell dishes were scraped at $4^{\circ} \mathrm{C}$ and quickly homogenized in a final vol of 2 $\mathrm{ml}$ of homogenization buffer [ $(50 \mathrm{mmol} /$ liter Hepes, $\mathrm{pH} 7.6,0.15 \mathrm{~mol} /$ liter $\mathrm{NaCl}, 1 \mathrm{mmol} /$ liter bacitricin, $1,000 \mathrm{U} / \mathrm{ml}$ of aprotinin, $1 \mathrm{mmol} /$ liter PMSF, $5 \mathrm{mmol} / \mathrm{liter}$ EGTA, 1\% Triton X-100 (wt/vol), and 50 $\mathrm{mmol} /$ liter BAEE)]. After incubation at $4^{\circ} \mathrm{C}$ for $1 \mathrm{~h}$, homogenates were centrifuged at 38,000 rpm for $1 \mathrm{~h}$ in a 40.3 rotor (Beckman Instruments, Inc., Palo Alto, CA), and the resultant solubilized extract (supernatant) chromatographed on a column containing $2 \mathrm{ml}$ of wheat germ agglutinin agarose. Lectin-bound insulin receptor activity was eluted with $2 \mathrm{ml}$ of column buffer containing $0.3 \mathrm{~mol} /$ liter of $N$-acetylD-glucosamine, and the eluted material used for measurement of insulin binding, insulin receptor autophosphorylation, insulin receptor-associated tyrosine kinase activity, and affinity labelling of insulin receptors. Protein concentration of eluates was determined by assay (Bio-Rad) (13) and 7-10 $\mu \mathrm{g}$ of protein were used to perform the following assays.

Insulin binding of the solubilized insulin receptor. Determination of insulin binding was performed as described before (19). In brief, an aliquot of partially purified receptors was incubated with $\mathrm{A} 14^{125} \mathrm{I}$ insulin and increasing concentration of unlabeled porcine insulin $(0.05$ $\mathrm{nmol} / \mathrm{liter}-0.15 \mathrm{nmol} / \mathrm{liter}$ ). Nonspecific binding was determined by addition of $0.7 \mu \mathrm{mol} /$ liter unlabeled insulin, and this amount subtracted from the radioactivity bound at the other insulin concentrations. Data were analyzed using the method of Scatchard (20). Values of $B_{\max }$ were calculated with the help of computer software adapted for the Macintosh by Macpherson et al. (Elsevier-Biosoft, Cambridge, UK), and designated "binding."

Insulin stimulated tyrosine kinase activity. Partially purified receptors were preincubated with increasing concentrations of insulin ( 0 $300 \mathrm{nmol} /$ liter). Phosphorylation was initiated by the addition of $50 \mu \mathrm{l}$ of reaction mixture containing $50 \mu \mathrm{mol} /$ liter $\left(\gamma^{32} \mathrm{ATP}\right)(30 \mathrm{Ci} / \mathrm{nmol})$, $20 \mathrm{mmol} /$ liter $\mathrm{MgCl}_{2}, 25 \mathrm{mmol} / \mathrm{liter} \mathrm{ATP}$, and $2 \mathrm{mg} / \mathrm{ml}$ [poly $\left(\mathrm{GLU}^{80}: \mathrm{Tyr}^{20}\right)$ ], and terminated $15 \mathrm{~min}$ later by applying $50 \mu \mathrm{l}$ of the reaction mixture to separate phosphocellulose filter paper squares and washing extensively with $75 \mathrm{mM}$ phosphoric acid (21). The amount of ${ }^{32} \mathrm{P}$ incorporated into [poly $\left(\mathrm{GLU}^{80}: \mathrm{Tyr}^{20}\right)$ ] was determined by liquid scintillation counting. Tyrosine kinase activity was expressed as picomoles ${ }^{32} \mathrm{P}$ incorporated into [poly $\left(\mathrm{GLU}^{80}: \mathrm{Tyr}^{20}\right)$ ] per minute per milligram of total cellular protein.

Insulin receptor autophosphorylation. Partially purified insulin receptors were incubated with increasing concentrations of insulin $(0.03-$ $300 \mathrm{nmol} /$ liter) for $60 \mathrm{~min}$ at room temperature. Autophosphorylation was initiated by the addition of $\gamma^{32} \mathrm{ATP}(50 \mu \mathrm{mol} / \mathrm{liter})(30 \mathrm{Ci} / \mathrm{mmol})$ and $\mathrm{MnCl}_{2}(5 \mathrm{mmol} / \mathrm{liter})$. All samples were analyzed by SDS page and autoradiography (22).

Affinity labeling of insulin receptors. Partially purified receptors were incubated with $0.5 \mu \mathrm{Ci}$ of $\mathrm{B}^{26}{ }_{-125} \mathrm{I}$ insulin in the presence or absence of unlabeled insulin $(0.7 \mu \mathrm{mol} / \mathrm{liter})$ for $24 \mathrm{~h}$ at $4^{\circ} \mathrm{C}$. Disuccinimidyl suberate $(2 \mathrm{mmol} / \mathrm{liter})$ was then added for $15 \mathrm{~min}$ at $4^{\circ} \mathrm{C}$ and samples analyzed by SDS page followed by radioautography (22).

Cellular triglyceride content. Cellular triglyceride content was determined in two wells by means of a kit (Sigma Chemical Co., St. Louis, MO) $(23,24)$, and expressed per milligram protein.

Glucose transport. Cells from two plates were washed thoroughly with phosphate buffer and then preincubated in serum-free and insulin-free medium for $2 \mathrm{~h}$. Wells were incubated for $10 \mathrm{~min}$ in the presence of increasing concentrations of insulin (0-2 nmol/liter), and the incubation continued for another $5 \mathrm{~min}$ after addition of 2-desoxyglucose ${ }^{14} \mathrm{C}$. The incubation was terminated by three successive washings with phosphate buffer and the amount of cellular radioactivity determined by liquid scintillation counting.

\section{Statistical analysis}

All data were expressed as mean \pm SEM, and analyzed by one-way and two-way analysis of variance $(25,26)$, and Student's paired $t$ test.

\section{Results}

Precursor cells derived from the SV fractions of all three regions were plated at $5 \times 10^{5}$ cells/well and reached near confluence 4-5 d after plating, at which time they had a fibroblasttype morphology. At this point the FCS was reduced from $10 \%$ to $1 \%$, insulin decreased from 0.01 to $1 \mathrm{nmol} /$ liter, and intralipid added. After another $10 \mathrm{~d}$ in culture, $\sim 80 \%$ of the cells were engorged with lipid regardless of anatomical site.

\section{A. Cell growth and differentiation}

Results in Fig. 1 demonstrate that both cell number and protein content expressed per dish were identical in EPI, RP, and $\mathrm{SC}$ cultures. The protein content per cell was essentially identical in all three cell types $\left(\sim 0.60 \mathrm{mg}\right.$ protein $/ 10^{6}$ cells $)$. Consequently, the remainder of the data are expressed per milligram of total cellular protein. Fig. $2 A$ shows that SV cells obtained from EPI, RP, and SC cells expressed the same level of LPL activity $10 \mathrm{~d}$ postplating. In addition, the data in Fig. $2 B$ show 

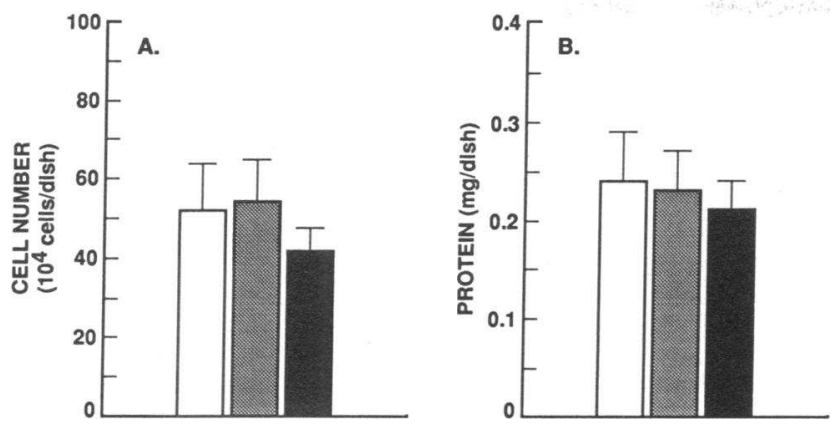

Figure 1. Cell number and protein content of newly differentiated adipocytes cultured from three different adipose tissue sites: EPI, RP, and SC. Values represent means \pm SEM of seven experiments of cells

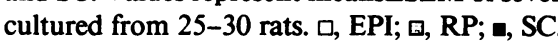

that there were no significant differences between the GPDH activity of cell cultures obtained from the EPI, RP, and SC regions $(n=7)$. Assuming that the activity of these two enzymes provides a good marker of differentiation, these data indicate that EPI, RP, and SC cultures have reached an equal level of differentiation.

\section{B. Insulin receptor characteristics}

${ }^{125}$ I Insulin binding to intact cells. Cellular insulin binding activity was assessed by incubating adhering cells directly with ${ }^{125} \mathrm{I}$ labeled insulin in the presence of increasing concentrations of unlabeled insulin. The resulting competition curves were then transformed into Scatchard plots (19). In each case, equilibrium insulin binding was characterized by a nonlinear Scatchard plot, suggesting the presence of high and low affinity binding components (Fig. 3). Mean high affinity binding constants from eight experiments are summarized in Table $I$, and show that both total insulin binding and the affinity $\left(K_{d}\right)$ of insulin for its receptor were similar in intact cells regardless of anatomical location.

${ }^{125}$ I Insulin binding to isolated and partially purified receptors. Scatchard plots of ${ }^{125} \mathrm{I}$-insulin binding to partially purified receptor preparation from the three different sites are shown in Fig. 4, and in this case it is clear that a linear relationship was observed. The results of six experiments are summarized in Table II, and it can be seen that both total insulin binding and
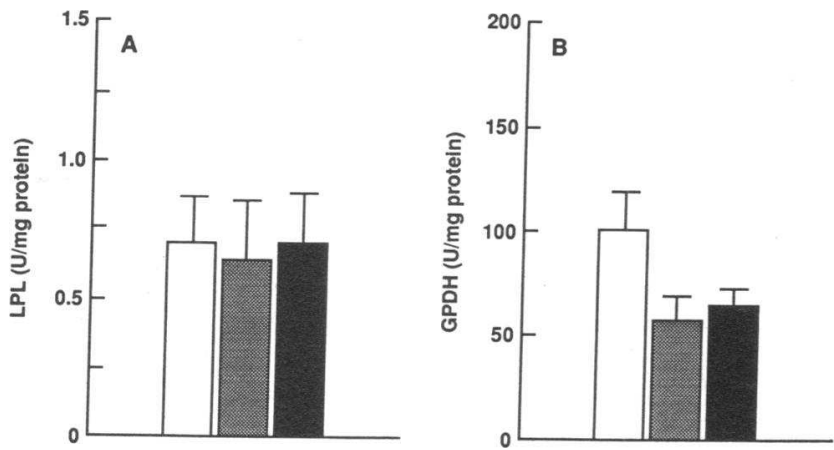

Figure 2. Heparin releasable LPL activity and GPDH activities of newly differentiated adipocytes cultured from three different adipose tissue sites: EPI, RP, and SC. Values represent means \pm SEM of seven experiments of cells cultured from 25-30 rats. $\square$, EPI; $₫$, RP; $\approx$, SC.

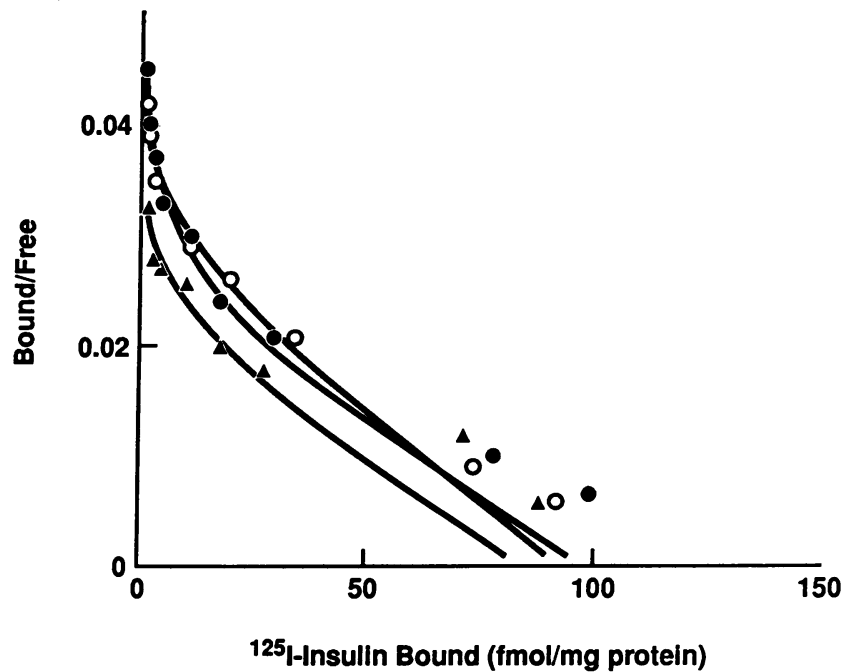

Figure 3. Scatchard plot analysis of $\mathrm{A}^{14}$-125 $^{12}$-insulin binding to newly differentiated adipocytes cultured from three different adipose tissue sites: EPI, RP, and SC. Curves were drawn using a French ruler. $O$, EPI; •, RP; $₫$, SC.

the affinity of insulin for its receptor $\left(K_{d}\right)$ were similar irrespective of the source of the partially purified receptors.

Insulin receptor tyrosine kinase activity. The ability of different concentrations of insulin to stimulate phosphorylation of exogenous substrate [poly $\left(\mathrm{GLU}^{80}: \mathrm{Tyr}^{20}\right)$ ] by lectin-purified receptor preparations is shown in Fig. 5, and it is apparent that insulin produced a dose-dependent increase in tyrosine kinase activity in all three types of preparations of receptors. The numerical values for basal (in the absence of insulin) and insulinstimulated maximal tyrosine kinase activity are shown in Table III. Although basal activity was similar in the three receptor preparations, maximal insulin-stimulated tyrosine kinase activity, (expressed either as milligrams protein or normalized to insulin binding) was lower by $\sim 50 \%$ in receptor preparations derived from the SC region as compared to EPI and RP derived cells $(P<0.05)$. However, no significant differences were observed in the sensitivity $\left(K_{\mathrm{a}}\right)$ of insulin-stimulated tyrosine kinase activity in the three cell populations.

Insulin-stimulated autophosphorylation of the $\beta$-subunit of the insulin receptor. Autophosphorylation of $\beta$-subunit of the insulin receptor was only studied in cells derived from the EPI

Table I. Insulin Binding to Newly Differentiated Adipocytes from Three Anatomical Sites

\begin{tabular}{lccc}
\hline Site & $n$ & Maximal insulin binding & $K_{\mathrm{d}}$ \\
\hline & & $\mathrm{fmol} \cdot \mathrm{mg}^{-1}$ protein & $n M$ \\
EPI & 8 & $92 \pm 23$ & $2.4 \pm 0.5$ \\
RP & 8 & $95 \pm 19$ & $2.4 \pm 0.5$ \\
SC & 8 & $82 \pm 20$ & $2.6 \pm 0.5$
\end{tabular}

Insulin binding activity measured on intact cells is expressed as fmoles $A^{14}{ }^{125}$ I-labeled monoiodoinsulin bound/mg total cellular protein. Estimates of binding sites (receptor concentration $B_{\max }$ and hormone affinity of the receptor $K_{d}$ were derived from Scatchard plots). Values are means \pm SEM of eight separate experiments, using differentiated cells obtained from the SV fraction of 25-30 rats. 


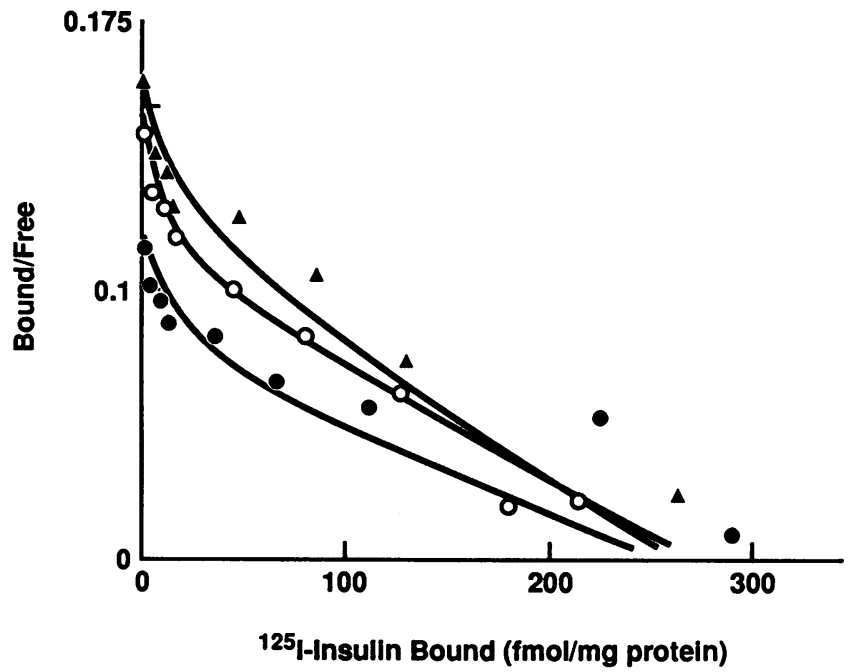

Figure 4. Scatchard plot analysis of $\mathrm{A}^{14}{ }^{125} \mathrm{I}$-insulin binding to partially purified insulin-receptor preparations of newly differentiated adipocytes cultured from three different adipose tissue sites: EPI, RP, and SC. Curves were drawn using a French ruler. O, EPI; ๑, RP; $\Delta$, SC.

and SC regions. Partially purified receptor preparations of these cells were incubated with ${ }^{32} \mathrm{ATP}$, in the presence of $(0-$ $300 \mathrm{mmol} / \mathrm{liter}$ ) insulin and subjected to SDS PAGE radioautography. As shown in Fig. 6, phosphorylation of these receptor preparations resulted in the labeling of one peptide band of mol wt of $\sim 95 \mathrm{kD}$, and the amount of ${ }^{32} \mathrm{P}$ incorporated into this band increased proportionately with the insulin concentration in the incubation mixture. Quantification of the ${ }^{32} \mathrm{P}$ incorporation into the $95-\mathrm{kD}$ band, presented in Table IV, shows that the isolated SC receptor preparations incorporated less ${ }^{32} \mathrm{P}$ than did preparations from the EPI regions, expressed as either total activity or activity per unit of insulin receptor activity $(P$ $<0.05$ ).

Affinity labeling of insulin receptors. To test the possibility that the insulin receptor alpha subunit might vary with tissue source, solubilized and partially purified receptor preparations derived from either the EPI or SC regions were equilibrated with $\left.\mathrm{B}^{26}{ }^{125} \mathrm{I}\right)$-insulin and covalently cross-linked to bound insulin. The data in Fig. 7 show that no detectable differences in the affinity labeling pattern of alpha subunits were noted between cells from EPI or SC cultures.

Table II. Insulin Binding to Partially Purified Insulin Receptors of Newly Differentiated Adipocytes from Three Anatomical Sites

\begin{tabular}{lccc}
\hline Site & $n$ & Maximal insulin binding & $K_{d}$ \\
\hline & & $f m o l \cdot m^{-1}$ protein & $n M$ \\
EPI & 6 & $255 \pm 42$ & $0.19 \pm 0.06$ \\
RP & 6 & $248 \pm 36$ & $0.12 \pm 0.03$ \\
SC & 6 & $250 \pm 54$ & $0.20 \pm 0.09$
\end{tabular}

Insulin binding activity measured on partially purified receptors is expressed as fmoles $\mathrm{A}^{14}$ - $^{125} \mathrm{I}$-labeled monoiodoinsulin bound/mg total cellular protein. Estimates of binding sites (receptor concentration $B_{\max }$ and hormone affinity of the receptor $K_{d}$ were derived from Scatchard plots). Values are means \pm SEM of six separate experiments, using differentiated cells obtained from the SV fraction of 25-30 rats.

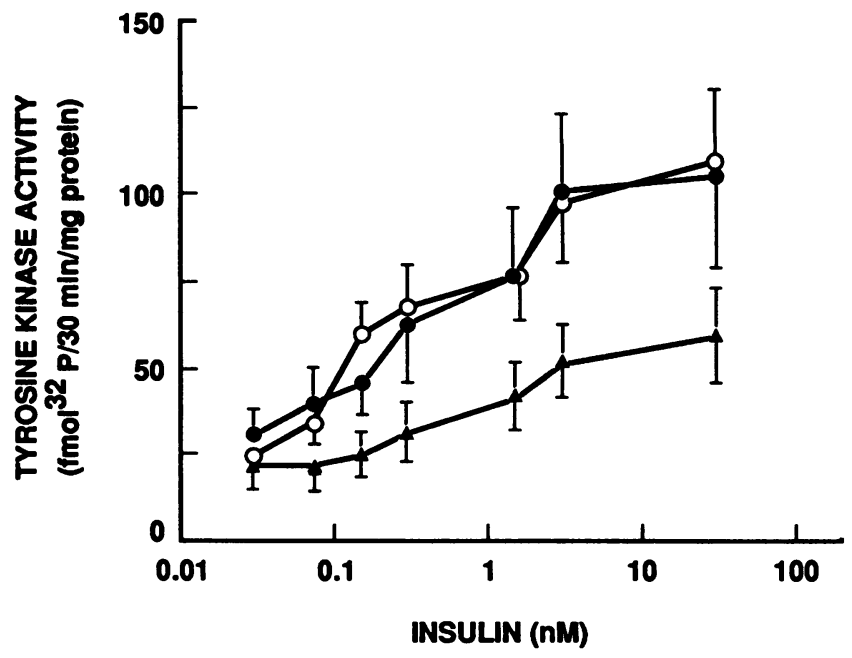

Figure 5. Insulin-stimulated tyrosine kinase activity of partially purified insulin receptors of newly differentiated adipocytes cultured from three different adipose tissue sites: EPI, RP, and SC. Values represent means \pm SEM of six experiments of cells cultured from 25-30 rats. O, EPI; •, RP; $\triangle$, SC.

\section{Insulin action}

Despite the fact that cells derived from all three regions were cultured in the same insulin concentration ( $1 \mathrm{nmol} / \mathrm{liter})$, cellular triglyceride content was significantly higher $(P<0.05)$ in EPI-derived cells $(25.6 \pm 5 \mathrm{mg} / \mathrm{mg}$ protein) than in cells derived from either the RP $(15.8 \pm 2.2 \mathrm{mg} / \mathrm{mg}$ protein $)$ or $\mathrm{SC}(10.8 \pm 1.3$ $\mathrm{mg} / \mathrm{mg}$ protein) regions.

Table III. Basal and Maximal Insulin-Stimulated Tyrosine Kinase Activity of Partially Purified Insulin Receptors from Newly Differentiated Adipocytes from Three Anatomical Sites

\begin{tabular}{lccccc}
\hline & & \multicolumn{3}{c}{$\begin{array}{c}\text { Maximal } \\
\text { insulin-stimulated } \\
\text { tyrosine kinase } \\
\text { activity/pmol of } \\
\text { insulin-binding } \\
\text { activity }\end{array}$} & \\
Site & $n$ & $\begin{array}{c}\text { Basal tyrosine } \\
\text { kinase activity* }\end{array}$ & $\begin{array}{c}\text { Maximal insulin- } \\
\text { stimulated tyrosine } \\
\text { kinase activity*t }\end{array}$ & & $n M$ \\
& & & & & \\
EPI & 6 & $13.9 \pm 4.5$ & $94.9 \pm 15.9$ & $0.46 \pm 0.12$ & $1.1 \pm 0.2$ \\
RP & 6 & $26.9 \pm 7.6$ & $88.2 \pm 21.8$ & $0.59 \pm 0.22$ & $1.6 \pm 0.3$ \\
SC & 6 & $11.7 \pm 5.2$ & $46.9 \pm 9.4$ & $0.23 \pm 0.07$ & $2.1 \pm 0.4$
\end{tabular}

Insulin receptor tyrosine kinase activity. Basal tyrosine kinase activity and total insulin-stimulated tyrosine kinase activity are expressed as fmoles ${ }^{32} \mathrm{P}$ incorporated into poly $\left(\mathrm{Glu}^{80}: \mathrm{Tyr}^{20}\right) \cdot \mathrm{min}^{-1} \cdot \mathrm{mg}$ total cellular protein. Maximal insulin-stimulated tyrosine kinase activity is also normalized to insulin binding and expressed as $\mathrm{fmol}{ }^{32} \mathrm{P}$ incorporated into poly $\left(\mathrm{Glu}^{80}: \mathrm{Tyr}^{20}\right) \cdot \mathrm{min}^{-1} \cdot \mathrm{fmol}^{-1}$ insulin binding activity. Values are means \pm SEM of six separate experiments, using differentiated cells obtained from the SV fraction of 25-30 rats. The EPI and RP values significantly exceed the SC value $(P<0.05$, analysis of variance).

${ }^{*}$ Tyrosine kinase activity is expressed as $f m o l$ poly $\left(\mathrm{Glu}^{80} \mathrm{Tyr}^{20}\right) \cdot \mathrm{mg}^{-1} \cdot 30 \mathrm{~min}$. ${ }^{*}$ Total insulin-stimulated $(30 \mathrm{nM})$ tyrosine kinase activity minus basal activity. ${ }^{6}$ Tyrosine kinase activity is expressed as fmol ${ }^{32} \mathrm{P}$ incorporated into poly $\left(\mathrm{Glu}^{80} \mathrm{Tyr}^{20}\right) \cdot \mathrm{mg}^{-1} \cdot 30$ $\mathrm{min} \cdot \mathrm{fmol}^{-1}$ insulin binding activity. 

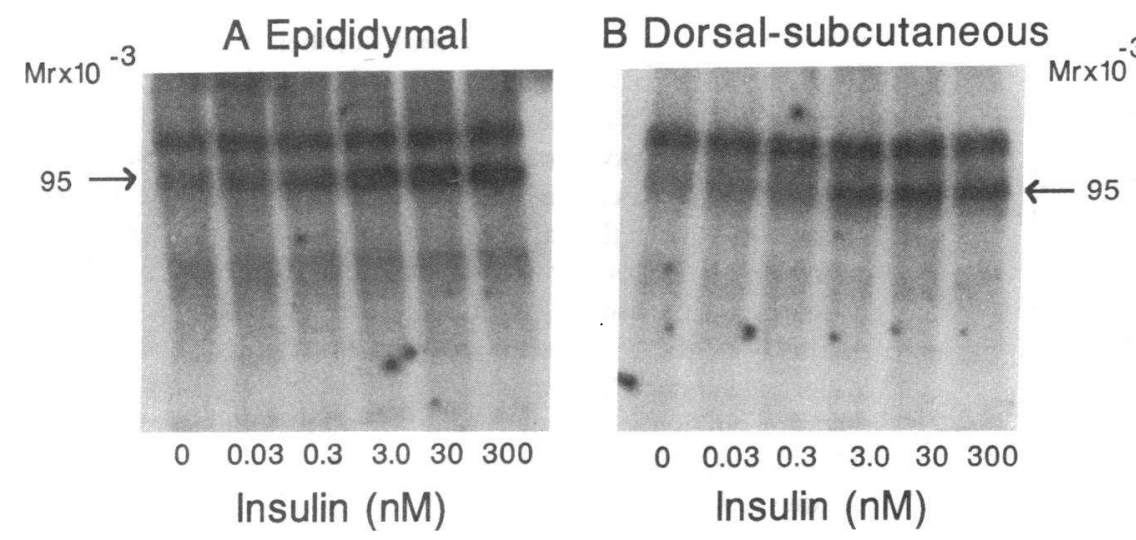

Figure 6. Dose dependent effect of insulin on B subunit phosphorylation of the insulin receptor. Insulin-stimulated phosphorylation of the $\beta$-subunit of partially purified insulin receptors of newly differentiated adipocytes cultured from two different adipose tissue sites: EPI and SC. Partially purified insulin receptors were incubated with $\gamma^{32} \mathrm{ATP}$ in absence or in presence of various amounts of insulin. The insulin receptor is identified as mol wt of 95,000 . Standard proteins were run in parallel: myosin (200 kD), b galactosidase (116.3 kD), phosphorylase b (92.5 kD), BSA (66.2 kD), ovalbu$\min (45.0 \mathrm{kD})$, carbonic anhydrase $(31.0 \mathrm{kD})$, soybean trypsin inhibitor $(21.5 \mathrm{kD})$, and lysosyme (14.4 kD).
Anatomical site also affected insulin-stimulated 2-deoxy-D glucose uptake as shown in Fig. 8. It can be seen that maximal insulin-stimulated 2-deoxyglucose-D uptake by SC cells was significantly reduced when compared to the cells from the other two regions $(P<0.05)$. Furthermore, maximal insulinstimulated glucose uptake by RP cells was intermediate. However, the $\mathrm{EC}_{50}$ values for insulin stimulation above basal were similar in cells from the EPI $\left(5.4 \times 10^{-8} \mathrm{M}\right), \operatorname{RP}\left(7 \times 10^{-8} \mathrm{M}\right)$, and $\mathrm{SC}\left(7.5 \times 10^{-8} \mathrm{M}\right)$ regions.

\section{Discussion}

The goal of these experiments was to test the hypothesis that adipose tissue would demonstrate differences in insulin action as a function of anatomical site. We also wished to evaluate this issue under conditions which would permit us to see if any variations in insulin action that were observed could be attributed to intrinsic characteristics of the newly differentiated adipocytes as a function of their anatomical site of origin. For this purpose, SV cells were isolated from adipose tissue obtained from three different anatomical locations: EPI, RP, and SC, and allowed to differentiate into mature adipocytes in primary tissue culture. Under these conditions it was possible to demonstrate the existence of significant differences in insulin action as a function of the anatomic site of origin of the stromal vascular fraction. Indeed, the only facet of insulin action that did not

Table IV. Insulin-Stimulated Phosphorylation of the B-Subunit of Partially Purified Insulin Receptors of Newly Differentiated Adipocytes Cultured from Two Adipose Tissue Sites

\begin{tabular}{lccc}
\hline Site & $n$ & Maximal activity & Maximal activity \\
\hline & & arbitrary units $\cdot \mathrm{mg}^{-1}$ & arbitrary units $\cdot \mathrm{fmol}^{-1} \cdot \mathrm{mg}^{-1}$ \\
EPI & 3 & $3.5 \pm 1.1$ & $2.7 \pm 0.1$ \\
SC & 3 & $1.2 \pm 0.5$ & $1.4 \pm 0.5$
\end{tabular}

Insulin-stimulated autophosphorylation of $\beta$-subunit receptor. Maximal insulin-stimulated autophosphorylation is expressed as ${ }^{32} \mathrm{P}$ incorporated in the $95-\mathrm{kD}$ band analyzed by densitometry (arbitrary units). Maximal insulin-stimulated tyrosine kinase activity is also normalized to insulin binding and expressed as ${ }^{32} \mathrm{P}$ incorporated $\cdot \mathrm{fmol}^{-1} \cdot \mathrm{mg}^{-1}$ total cellular protein. Values are means $\pm \mathrm{SEM}$ of three separate experiments, using differentiated cells obtained from the SV fraction of 25-30 rats. The EPI value significantly exceds the SC value $(P<0.05$, paired $t$ test $)$. vary with source of adipose tissue was insulin binding. The results presented indicated that when insulin binding was measured in either intact cells or in partially purified receptor preparations that the number of cellular insulin receptors and the affinity of insulin for its receptors were found to be similar for cells from all three locations. In contrast, insulin receptor phosphorylation activity was found to vary significantly between cells derived from the three regions, and differences were noted between the ability of insulin to phosphorylate its own receptor, as well as to stimulate phosphorylation of an exogenous substrate. More specifically, insulin receptor phosphorylating activity was markedly decreased in cells from the SC region, as compared to EPI and RP-derived cells. These differences were observed when activity was expressed per milligram protein or per insulin receptor, and were independent of any changes in the affinity labeling of the $\alpha$ subunit of the insulin receptor. To

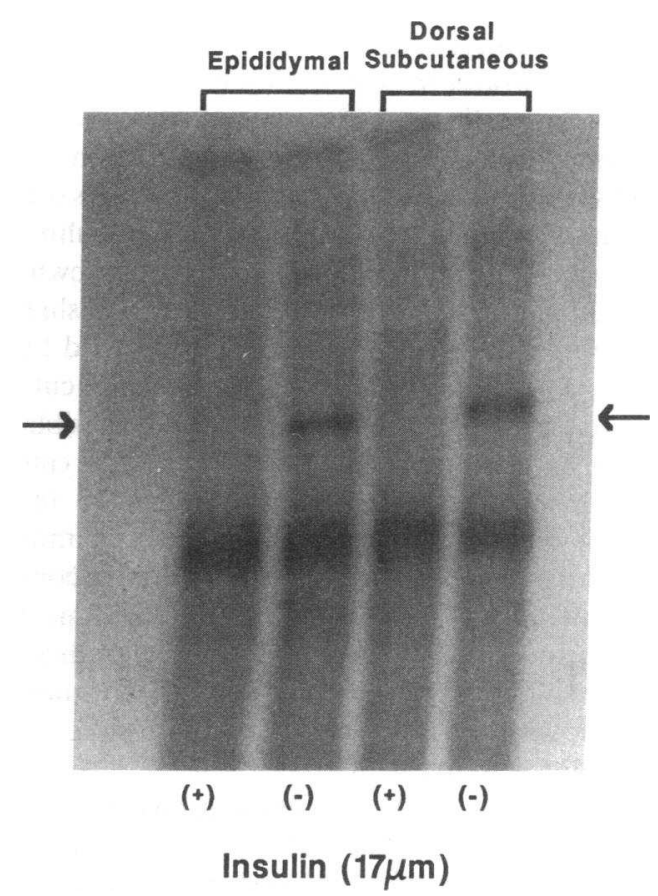

Figure 7. Affinity labeling of $\alpha$-subunit of insulin receptor with $\left[{ }^{125}\right.$ ] $] B-26$ insulin from newly differentiated adipocytes derived from the epididymal and subcutaneous fat depots. Partially purified receptors were incubated with $\mathrm{B}^{26}{ }^{125} \mathrm{I}$ monoiodoinsulin in the presence (+) or the absence (-) of unlabeled insulin $(0.7 \mu \mathrm{mol} /$ liter $)$. 


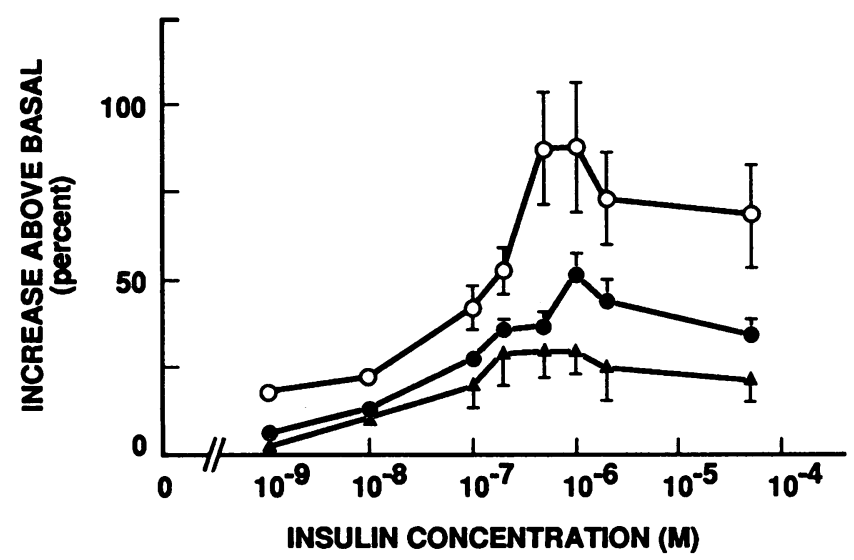

Figure 8 . Glucose uptake by newly differentiated adipocytes cultured from three different adipose tissue sites: EPI, RP, and SC. Values represent the means \pm SEM of eight experiments of cells cultured from 25-30 rats. ০, EPI; ๑, RP; $\triangle$, SC.

the best of our knowledge, this is the first demonstration that differences in insulin receptor phosphorylating activity can be observed between fat cells isolated from different anatomical locations.

The changes noted in insulin receptor phosphorylating activity were quite consistent with the measurements made of the biological activity of insulin. Thus, cellular triglyceride content was highest in EPI-derived cells and lowest in cells from the SC region, with RP cells being intermediate. Since culture insulin concentration was similar in all three cell population, these data suggest that differences in the lipogenic effect of insulin were consistent with the effect that regional fat distribution had on insulin receptor phosphorylating activity. Similarly, the results in Fig. 8 indicate that the ability of insulin to stimulate glucose uptake in newly differentiated adipocytes was greatest in EPI-derived cells and lowest in cells from the SC region. It should be noted that the qualitative differences we observed in maximal insulin-stimulated glucose uptake as a function of source of adipose tissue are consistent with previous studies on freshly isolated adipocytes (27). However, maximal insulinstimulated glucose uptake by differentiated adipocytes grown in primary tissue culture is much lower than that seen in freshly isolated cells. Moreover, the insulin concentration needed to achieve maximal response is also higher in cells grown in culture as compared to freshly isolated adipocytes. One possible explanation is that cultured cells are deprived of fetal calf serum during the incubation time, possibly leading to increased basal glucose uptake and less response to insulin stimulation of glucose uptake. Irrespective of these quantitative considerations, the results in Fig. 8 clearly show that anatomical site of adipocyte precursor cells modulates the ability of these cells to respond to insulin, and the observed changes in insulin action are consistent with the differences noted in insulin receptor phosphorylating activity.

We would like to suggest that the results presented demonstrate that there are differences in the response of adipose tissue to insulin as a function of anatomical site, and that the changes noted are intrinsic to adipocytes isolated from these regions. To draw both of these conclusions we carried out these experiments in cells that were initially isolated from the SV fraction ("preadipocytes") from three different fat depots, and permitted these cells to differentiate into adipocytes in primary cul- ture. In this manner we have attempted to control for the differences in adipocyte cell size and number that occur when adipocytes are isolated from the same three regions (28), as well as avoiding any confounding variables that might result from differences in blood flow, local hormonal effects, etc., that might play a role in in vivo modulation of adipose tissue metabolism. Obviously, the validity of our conclusion will depend to a large extent upon the appropriateness of our tissue culture system. In this context, although it has been shown that the majority of the SV fraction isolated from adipose tissue will differentiate into "adipocyte-like" cells $(29,30)$, they will not acquire all of the characteristics of mature adipocytes (31). More importantly, the results of several previously published studies $(32,33)$ had clearly shown that significant differences in degree of adipocyte differentiation were observed when SV cells from the RP and EPI regions were grown in culture. If it was not possible to establish culture conditions under which adipocyte precursor could develop all of the characteristics of mature fat cells, we had to at least establish culture conditions permitting SV cells derived from the EPI, RP, and SC regions to differentiate to the same extent. Indeed, if this could not be accomplished, interpretation of our results would be significantly confounded. For several reasons we believe that we have satisfied this criterion. In the first place, cell size and number were similar in the culture-derived adipocytes, irrespective of source of the initial SV cells. Protein content of the three populations of cells was also similar. Finally, the activities of lipoprotein lipase and glycerophosphate dehydrogenase considered to be good markers for adipocyte differentiation (34), did not vary as a function of where the newly differentiated adipocytes came from. Thus, there is evidence that the tissue culture conditions employed in these experiments resulted in an equal degree of differentiation toward mature fat cells of SV cells isolated from three anatomically different fat depots. As such, they lend support to the view that the changes in insulin action described are intrinsic characteristic of adipose tissue from the three regions studied. However, the possibility remains that the changes noted are due to culture-specific differences in cell differentiation and development, and may not reflect processes which are important in vivo. On the other hand, cells from the dorsal subcutaneous region in older Sprague-Dawley rats have been shown to be significantly smaller than cells from either epididymal or retroperitoneal cells. It is apparent that this observation could account for the differences in the insulin receptor function described in our studies.

In conclusion, we believe that the data presented provide the first evidence that insulin receptor autophosphorylation and tyrosine kinase activity of the insulin receptor in adipose tissue varies as a function of its anatomical site. In addition, we have shown that these changes at the level of the insulin receptor are consistent with differences noted in the ability of insulin to modulate lipogenesis and glucose transport. By carrying out these experiments on newly differentiated adipocyte grown in primary culture, it can be speculated that all of the observed changes are intrinsic to fat tissue from these three sites. It is always dangerous to extrapolate data from one species to another, but the results presented raise the possibility that the regional differences in adipocyte metabolism described in human beings (35) may also reflect the unique behavior of these cells. Given the apparent importance of differences in regional fat distribution in human disease $(3,4,36)$, the implication of these findings is self-evident. 


\section{Acknowledgments}

We wish to give a special thank you to Dr. Judith Stern of University of California at Davis for her support and assistance in the early stages of this study.

Supported in part by research grants from the Research Service of the Department of Veterans Affairs, Weight Watchers, T32-K National Institutes of Health, and the Diabetes Research Foundation.

\section{References}

1. Rabinowitz, D., and K. L. Zierler. 1962. Forearm metabolism in obesity and its response to intra-arterial insulin. Characterization of insulin resistance and evidence for adaptive hyperinsulinism. J. Clin. Invest. 41:2173-2181.

2. Koltermann, O. G., J. Insel, M. Saekow, and J. M. Olefsky. 1980. Mechanisms of insulin resistance in human obesity. Evidence for receptor and postreceptor defects. J. Clin. Invest. 65:1272-1284.

3. Kissebah, A. H., N. Vydelingum, R. Murray, D. J. Evans, A. J. Hartz, R. K. Karlkoff, and P. W. Adams. 1982. Relation of body fat distribution to metabolic complications of obesity. J. Clin. Endocrinol. \& Metab. 54:254-260.

4. Bjorntorp, P. 1988. Abdominal obesity and the development of noninsulindependent diabetes mellitus. Diabetes Metab. Rev. 4:615-622.

5. Salans, L. B., S. W. Cushman, and R. E. Weissman. 1973. Studies of human adipose tissue: adipose cell size and number in nonobese and obese patients. $J$. Clin. Invest. 52:929-941.

6. Krotkiewski, M., and P. Bjorntorp. 1975. The effect of dexamethasone and starvation on body composition and regional adipose cellularity in the rat. Acta Endocrinol. 80:667-675.

7. Evans, P. J., R.-G. Hoffman, R. D. Kalkhoff, and A. H. Kissebah. 1983. Relationship of androgenic activity to body fat topography, fat cell morphology and metabolic aberrations in menopausal women. J. Clin. Endocrinol. \& Metab. 57:304-310.

8. Arner, P. 1988. Role of antilipolytic mechanism in adipose tissue distribution and function in man. Acta Med. Scand. Suppl. 723:147-152.

9. Lafontan, M. L., A. Dang-Tran, and M. Berlan. 1979. Alpha-adrenergic antilipolytic effect of adrenaline in human fat cells of the thigh: comparison with adrenaline responsiveness of different fat deposits. Eur. J. Clin. Invest. 9:261266.

10. Bolinder, J., L. Kager, J. Ostman, and P. Arner. 1983. Differences at the receptor and postreceptor levels between human omental and subcutaneous adipose tissue in the action of insulin on lipolysis. Diabetes. 32:117-123.

11. Fried, S. K., M. Lavau, and F. X. Pi-Sunyer. 1982. Variations in glucose metabolism by fat cells from three adipose depots of the rat. Metabolism. 31:876883.

12. Rodbell, M. 1964. Metabolism of isolated fat cells. I. Effects of hormones on glucose metabolism and lipolysis. J. Biol. Chem. 239:375-380.

13. Bradford, M. 1976. A rapid sensitive method for the quantification of microgramme quantities of protein utilizing the principle of protein dye binding. Anal. Biochem. 72:248-252.

14. Nilsson-Ehle, P. A., S. Garfinkel, and M. C. Shotz. 1980. Lipolytic enzymes and plasma lipoprotein metabolism. Annu. Rev. Biochem. 49:667-693.

15. Glick, J. M., and G. H. Rothblat. 1980. Effects of metabolic inhibitors on the synthesis and release of lipoprotein lipase in cultured cells derived from the stromal-vascular fraction of rat adipose tissue. Biochim. Biophys. Acta. 618:163 172.

16. Wise, L. S., and H. Green. 1979. Participation of one isoenzyme of cytosolic glycerophosphate dehydrogenase in the adipose conversion of 3T3 cells. J. Biol. Chem. 254:273-275.

17. Gaben-Cogneville, A. M., B. Poussin, M. C. Chamblier, M. F. Forgue-Lafitte, and G. Rosselin. 1988. Development of insulin and epidermal growth factor receptors during the differentiation of rat preadipocytes in primary culture. Biochim. Biophys. Acta. 968:231-238.

18. Hedo, J. A., L. C. Harrisson, and J. Roth. 1981. Binding of insulin receptors to lectins: evidence for common carbohydrate determinants on several membrane receptors. Biochemistry. 20:3385-3393.

19. Reaven, G. H., H. Chang, B. B. Hoffman, and S. Azhar. 1989. Resistance to insulin-stimulated glucose uptake in adipocytes isolated from spontaneously hypertensive rats. Diabetes. 38:1155-1160.

20. Scatchard, G. 1949. The attractions of proteins for small molecules and ions. Ann. NY. Acad. Sci. 51:660-672.

21. Raskoski, R. J. R. 1983. Assay of protein kinase. Methods Enzymol. 99:3-6.

22. Laemmli, U. K. 1970. Cleavage of structural proteins during assembly of the head of bacteriophage $T_{4}$. Nature (Lond.). 227:680-685.

23. Dole, W. P. 1956. A relation between non-esterified fatty acid in plasma and the metabolism of glucose. J. Clin. Invest. 35:150-156.

24. Eggstein, M., and F. H. Kreutz. 1966. Eine neue Bestimmung der neutralfette in blut serum and gewebe. Klin. Wochenschr. 4:262-264.

25. Winer, B. J. 1971. Statistical principles in experimental design. McGrawHill Inc., New York. pp. 514-603.

26. Godfrey, K. 1985. Statistics in practice: comparing the means of several groups. N. Engl. J. Med. 313:1450-1456.

27. Foley, J. E., A. Kashiwagi, H. Chang, T. P. Huecksteadt, S. Lillioja, M. A. Verso, and G. M. Reaven. 1984. Sex differences in insulin-stimulated glucose transport in rat and human adipocytes. Am. J. Physiol. 246(Endocrinol. Metab. 9):E211-E215.

28. Bertrand, H. A. C. Stacy, E. J. Masaro, B. P. Yu, I. Murata, and H Maeda. 1984. Plasticity of fat cell number. J. Nutrit. 114:127-131.

29. Bjorntorp, P., M. Karlsson, H. Pertof, P. Pettersson, L. Sjostrom, and U. Smith. 1978. Isolation and characterization of cells from rat adipose tissue developing into adipocytes. J. Lipid Res. 19:316-324.

30. Sztalryd, C., and I. M. Faust. 1991. Depot-specific features of adipocyte progenitors revealed primary cultures plated at low density. Int. J. Obesity. In press.

31. Lu, Z. D., M. A. Pineyro, J. L. Kirkland, Z. H. Li, and R. I. Gregerman. 1988. Prostaglandin-sensitive adenylyl cyclase of cultured preadipocytes and mature adipocytes of the rat: probable role of $\mathrm{Gi}$ in determination of stimulatory or inhibitory action. J. Cell. Physiol. 136:1-12.

32. Djian, P., D. A. K. Roncari, and C. H. Hollenberg. 1985. Adipocyte precursor clones vary in capacity for differentiation. Metabolism. 34:880-884.

33. Djian, P., D. A. K. Roncari, and C. H. Hollenberg. 1983. Influence of anatomic site and age on the replication and differentiation of rat adipocyte precursors in culture. J. Clin. Invest. 72:1200-1208.

34. Wise, L. S., and H. Green. 1978. Studies of LPL during adipose conversion of 3T3 cells. Cell. 13:233-242.

35. Leibel, R. L., N. K. Edens, and S. K. Fried. 1989. Physiologic basis for the control of body fat distribution in humans. Annu. Rev. Nutr. 9:417-443.

36. Donahue, R. P., R. D. Abbott, E. Bloom, O. M. Reed, and K. Yano. 1987. Central obesity and coronary heart disease in men. Lancet. i:821-824. 